\title{
The Effect of Distance Learning on Learning Outcomes of Children with Special Needs in Inclusive Schools in the New Normal
}

\author{
Nur Indah Sholikhati ${ }^{1}$, Muhaimi Mughni Prayogo ${ }^{1}$, Joko Santoso ${ }^{1}$ \\ ${ }^{1}$ FKIP, Sarjanawiyata Tamansiswa University, Yogyakarta, Indonesia
}

\begin{abstract}
Distance education is an organized educational process that bridges the separation between students and educators mediated by the use of technology and minimal face-to-face meetings. Distance education evolved from correspondent education to education through e-learning across time and space. Currently, in Indonesia, even in all countries in the world there is an outbreak of Covid-19 which results in learning in the field of education having to change from face-to-face learning to distance learning. The purpose of this study was to determine how the effect of distance learning for children with special needs in inclusive schools in the new era of normality. The method used in this research is qualitative research with online interview data collection techniques, documentation, and literature studies related to children with special needs during the COVID 19 pandemic. Qualitative data analysis was carried out through the stages of data reduction, data presentation, concluding, and verification. Based on the purposive random sampling technique, this study involved 15 informants consisting of classroom teachers and Special Advisors from 12 inclusive schools in all districts in the Special Region of Yogyakarta. The results of the study revealed that distance learning which is applied in inclusive elementary schools in Yogyakarta is learning that is carried out online by utilizing various learning media both using the internet network and not Course materials are distributed online, communicated also carried out online, and all forms of examinations are also carried out online. The result of implementing distance learning in inclusive elementary schools is that learning the Indonesian language that is carried out remotely has a positive effect in the form of increased mastery of reading, listening, writing, and speaking competencies for children with special needs during the Covid-19 pandemic. The learning component that has the most influence is the selection of the learning media used. The more interactive the media used, the more effective the learning outcomes obtained by students. Even though online learning also encountered some obstacles, teachers continued to strive to improve the effectiveness of distance learning for children with special needs by collaborating with parents or guardians of students.
\end{abstract}

Keywords: distance learning, children with special needs, the Covid-19 pandemic

\section{Research Background}

Education is the process of changing the attitude and behavior of a person or group of people to mature humans through teaching and training efforts. In the National 
Education System Law No. 20 of 2003, the meaning of education is a conscious and planned effort to create an atmosphere of learning and the learning process so that students actively develop their potential to have religious-spiritual strength, self-control, personality, intelligence, noble character, and skills needed by themselves and society. Meanwhile, learning is a process of teaching and learning activities that also plays a role in determining student learning success. From the learning process, there will be an interactive activity between teacher-students and reciprocal communication that takes place in an educational situation to achieve learning goals (Rustaman, 2001: 461). In the learning process, teachers and students are two components that cannot be separated, and mutually supporting interactions must be established so that student learning outcomes can be achieved optimally. In line with this, Zain and Djamarah (1997: 50) also state that in a learning process, students need a teacher as a source of material in delivering material and knowledge for the development of student education and human resources.

After the emergence of the Covid-19 pandemic in various countries, including Indonesia, the education system began looking for innovation in the teaching and learning process. Moreover, Circular No. 4 of 2020 from the Minister of Education and Culture recommends that all activities in educational institutions must keep their distance and all material delivery will be delivered in their respective homes. Distance learning or commonly known as online learning is a solution so that learning can continue safely and is considered to be able to reduce the spread of Covid-19 effectively. Conceptually, distance learning is a learning process that does not involve direct contact between educators and students (Munir, 2009: 18). Distance learning is carried out without face to face but through an existing platform. All forms of subject matter are distributed online, communicated also done online, and all forms of examinations are also carried out online.

Distance learning carried out with an online system is considered to be a solution in carrying out the education process in a pandemic and new normality. Unfortunately, not all schools are ready for the implementation of distance learning. As reported in Jamal's (2020) study, it is necessary to increase the readiness of teachers, students, and school infrastructure to carry out distance learning. Especially inclusive schools that have heterogeneous students, namely regular students and students with special needs. Students with special needs in this case are children who have physical limitations: mental-intellectual; social; and emotional which has a significant impact on the process of growth or development compared to other children of his age (Winarsih, dkk., 2013). Based on the conditions experienced by students with special needs, the implementation of learning will be more effective if it involves students directly. With the current Covid-19 pandemic, the learning process for students or children with special needs (ABK) in inclusive schools is still a challenge in itself. 
A more real challenge in learning than for children with special needs in inclusive schools was conveyed by Anita, a teacher at an inclusive school who was a resource person in an article published on CNNIndonesia.com (2020). Anita (teacher/resource person) stated that online learning for children with special needs will experience many obstacles and obstacles if there is no collaboration between teachers and parents in accompanying learning at home. Anita gave an example experienced by one of the teachers at Inclusive Elementary School who had students with sensory processing disorder conditions. This condition makes it difficult for these students to absorb and respond to information that enters through their five senses due to obstacles in the brain. The first time this distance learning was implemented, the student insisted that he did not want to learn. It took days before the teacher and his parents were convinced to learn from home. Meanwhile, the teacher who is in charge of assisting students often feels anxious because the parents of these two students have to work in the office during the pandemic so that the parents of students cannot accompany them to study all the time.

Various field conditions revealed through the results of research and media articles show that distance learning for students with special needs during the new normality of the Covid-19 pandemic in practice varies widely and has various obstacles. But on the other hand, online learning practices will continue until the beginning of 2021. Based on this, further studies are needed to reveal the impact of implementing distance learning for students with special needs in inclusive schools in the current new era of normality.

Starting from this background problem, this study will present facts about the effect of distance learning on learning outcomes for children with special needs in inclusive schools in the new era of normality. The results of this study are expected to be able to provide information and reference for teachers, children with special needs, and parents in the face of the pandemic by learning from a distance.

\section{Research Methods}

\subsection{Study Design}

This research is qualitative research using the descriptive method. This research is structured as an inductive study, namely finding and collecting data in the field to know the factors, form elements, and the nature of phenomena in society (Nazir, 1998: 51).

Subjects in this study were selected using purposive random sampling technique based on criteria, namely (1) a public or private inclusion elementary school located in Yogyakarta, (2) willing to provide information about Indonesian language learning strategies applied to children with special needs in schools, (3) there are ABK students in the 2020/2021 school year, and (4) the variation in the presence or absence of GPK in schools. Based on these criteria, the research subjects were classroom teachers and Special Advisory Teachers (GPK) in 12 elementary schools in Yogyakarta (7 public schools in Yogyakarta City, 1 private school in Sleman Regency, 1 public school in Kulon Progo 
Regency, 1 private school in the Regency. Bantul, and 1 public and private school in Gunung Kidul Regency). The informants in this study were class teachers or GPK who were willing to provide information related to Indonesian language learning in 12 research locations schools. The total number of informants is 15 people.

In collecting data, this research uses interviews, documentation, and literature study methods. Semi-structured interviews were conducted with informants, namely class teachers and GPK at the research location schools. Semi-structured interviews were chosen so that researchers could more freely conduct in-depth interviews but still fit the data they wanted to reveal. Due to social restrictions, interviews will be conducted online. Meanwhile, the documentation method is used in documenting the results of interviews conducted online. The literature study method is used to obtain an overview of the research problem and examine the research results.

Sugiyono (2010: 335$)$ states that qualitative data analysis is the process of systematically searching and compiling data obtained from interviews, field notes, and documentation by organizing data into categories, describing them into units, synthesizing, compiling into patterns, choose which ones are important and what will be studied, and make conclusions so that they are easily understood by oneself and others.

Data processing was carried out by the data analysis stage by Miles and Huberman (in Sugiyono, 2010, pp. 338-345) which included three main components, namely data reduction, data display, and drawing conclusions and verification. Through this series of activities, in-depth information and valid data will be obtained about the school's response to the implementation of Indonesian language learning in inclusive schools in Yogyakarta. Then the valid data will be compiled in a narrative and critical manner in the form of a scientific research report that can be methodologically justified.

\section{Results and Discussion}

Learning that has been built up for years in school can be lost if there is no continuity with learning at home. This study aims to analyze the form of distance learning strategies for students with special needs in the Covid-19 pandemic era. This "new normal" or new normal does not mean students are prepared to return to school, but helps prepare students to be able to adapt to learning situations amid the Covid-19 outbreak.

\subsection{Differences in Learning Strategies Before and During the Covid-19 Pandemic}

There were several different things in teaching and learning in schools before and during the pandemic. A series of strategies must be carried out or even modified by an educator so that the learning process can be carried out effectively. As stated by Plt. Director-General of Early Childhood Education, Primary and Secondary Education, Ministry of Education and Culture of the Republic of Indonesia, Hamid Muhammad 
(Ministry of Education and Culture, 2020) explained that there are four main strategies carried out by the Ministry of Education and Culture as an effort to enforce Teaching and Learning Activities (KBM) amid the Covid-19 Pandemic. First, learning is carried out online, both interactively and noninteractively. Second, teachers or teachers must provide education to children about life skills, namely contextual education according to the conditions of their respective homes, especially the understanding of Covid-19, regarding its characteristics, how to avoid it, and how to prevent someone from being infected. Third, learning at home must be adapted to the interests and conditions of each child. Fourth, for teaching staff or teachers, assignments given to students do not have to be assessed as usual in school, but the assessment is more qualitative in nature which motivates children.

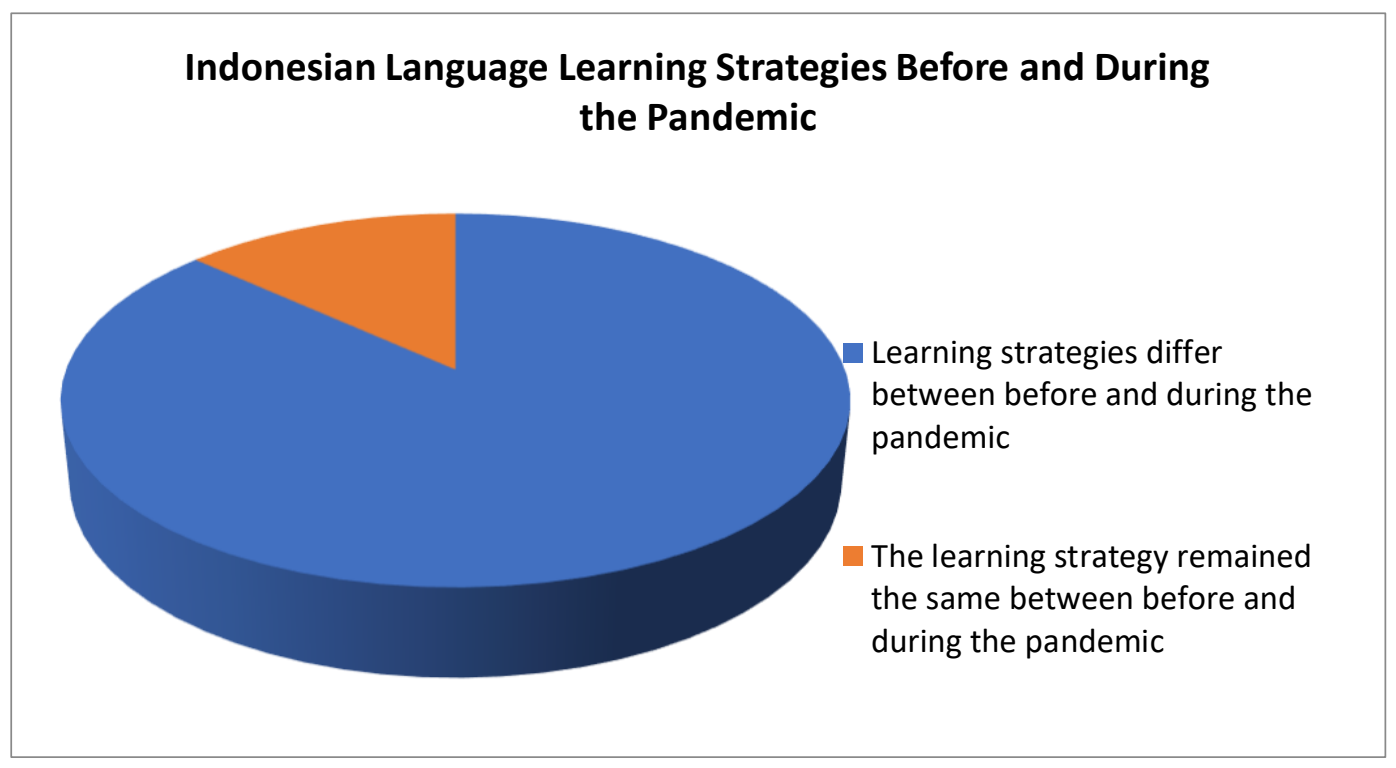

Diagram 1. Indonesian Language Learning Strategies Before and During the Pandemic

Referring to education policies to comply with health protocols, the Indonesian language learning strategy for children with special needs that was implemented during the pandemic has also changed. Based on the results of interviews from 15 informants, as depicted in diagram 1 , as many as $86.7 \%$ of the answers or 13 informants said there were differences in learning procedures and strategies between before the pandemic and during the Covid-19 pandemic.

This difference is made by the adaptation of learning strategies based on the conditions and abilities of students with special needs by emphasizing the modification and accommodation of learning strategies that include material, methods, media, and evaluation. Learning modifications can be given to students whose basic abilities are below the target of the class curriculum, such as slow learners, intellectual disabilities (mild and moderate), and autism. Meanwhile, the learning accommodation applied is the adjustment of methods in delivering material, learning media, and evaluation techniques 
that are adjusted to the ability of students' learning modalities to access information and respond to instructions. Accommodations can be applied simultaneously with modifications. Meanwhile, as many as $13.3 \%$ of the answers or 2 informants did not change the learning strategy or in the sense of continuing to use the same learning strategy as before the Covid-19 pandemic.

But in general, all informants continue to apply learning adaptations to the Covid19 pandemic situation according to the direction of the Ministry of Education \& Culture, namely by replacing face-to-face learning activities at school with learning from home with the application of contextual learning strategies. Learning from home utilizes technology as (1) an intermediary medium for teacher interaction with students and (2) technology as learning content. In addition, the application of contextual strategies in Indonesian language learning can also be seen in the assignment by teachers related to daily activities and utilizing existing learning resources in the surrounding environment, for example compiling descriptive texts of objects around students.

\subsection{Selection of Learning Media and Its Effects}

During the distance learning that has been implemented during this pandemic, the media used during distance learning varies widely. Of the 15 informants who have been interviewed, there are three types of learning media that are used in distance learning. The learning media used are visual media, audiovisual media, and multimedia media. The division of media types refers to the opinion of Cahyadi (2018) which classifies learning media into five types, namely audio media, visual media, audiovisual media, multimedia media, and reality media. However, in this study, only three types of media were found, which are detailed in Table 1.

Table 1. Types of Teaching Media in Learning for Children with Special Needs in Inclusive Schools in Yogyakarta During the Pandemic

\begin{tabular}{|l|c|l|}
\hline \multicolumn{1}{|c|}{ Types of media } & $\begin{array}{c}\text { Percentage of } \\
\text { Usage }\end{array}$ & \multicolumn{1}{|c|}{ Variations of learning media } \\
\hline Visual Media & $21,1 \%$ & $\begin{array}{l}\text { Learning modules, reading and writing } \\
\text { media, textbooks }\end{array}$ \\
\hline Audiovisual Media & $26,3 \%$ & Video, voice PPT \\
\hline Multimedia Media & $52,6 \%$ & $\begin{array}{l}\text { Youtube, video conferencing, WAG, e- } \\
\text { learning programs, Google Forms, } \\
\text { Google Classroom, Zoom }\end{array}$ \\
\hline
\end{tabular}

From the results of the interviews presented in Table 1, it is known that $21.1 \%$ of informants chose to use visual media with a variety of learning media as shown in Table 1. As many as $26.3 \%$ of informants also used variations of learning media from the type of audiovisual media with details as described depicted in the table. Meanwhile, the 
selection of multimedia media was mostly used by informants, with $52.6 \%$ claiming to use multimedia media in distance learning, especially using internet network-based teaching media.

Furthermore, the results of data collection revealed that the selection of varied learning media was based on considerations of student conditions and field conditions. In the selection of instructional media for children with special needs, as many as $93.3 \%$ of informants from different schools consider the condition of the child in choosing learning media. The condition of the child, in this case, is the child's cognitive ability to participate in learning, the tendency of children's learning styles, and children's interests. Meanwhile, as many as $6.7 \%$ of informants considered the conditions in the field in choosing learning media. Field conditions, in this case, are the availability of infrastructure, both at school and children's homes, and the affordability of teachers and parents in using the media.

The teacher's consideration in choosing instructional media is the basis for determining the media. The selection of learning media is based on the teacher's understanding of student learning styles (Cahyadi, 2018). Learning styles are determined by the learning modalities possessed by students. The learning modality itself relates to the ability of the sensory system to absorb information from the surrounding environment. This means that the selection of learning media is adjusted to the condition of students in terms of learning modalities possessed by students with special needs.

Based on the data exposure, it can be seen that class teachers and teachers accompanying special needs students in inclusive elementary schools have tried to implement distance learning by utilizing learning media according to the needs and abilities of students. As previously described, classroom teachers and special companion teachers have had basic considerations in selecting instructional media for children with special needs during the pandemic. These considerations are an indicator of choosing the type of learning media during the pandemic.

The use of learning media that is applied in this learning also affects the participation of special needs students in the distance learning process. As many as $60 \%$ or 9 informants said that students actively participate in the distance learning process with the help of parents. Meanwhile, as many as $40 \%$ or 6 informants admitted that this distance learning value was less effective because students became less enthusiastic and often encountered difficulties, especially if parents were busy working, while students were not able to learn independently.

Based on the data on participation in the distance learning process, it was found that the selection of learning media greatly influenced student participation in learning. The learning media used by the six informants who considered distance learning to be less effective included assignment media, videos, and WhatsApp Group. This shows that the 
use of visual or audiovisual media is unidirectional and passive. In contrast to teachers who use multimedia media which results in active participation from students, such as data presented in interviews. The use of multimedia media is felt to be more effective because of the interaction between teachers and students with the help of parents, such as video conference media, e-learning programs, Zoom meetings, or Youtube. In this case, it can be said that the selection of learning media greatly affects the learning process which is carried out remotely.

\subsection{Differences in Learning Outcomes of Students with Special Needs before and after the Application of Distance Learning}

The change in Indonesian learning strategies both in terms of learning media or teaching procedures, also directly affects Indonesian learning outcomes for children with special needs between before and after distance learning is implemented.

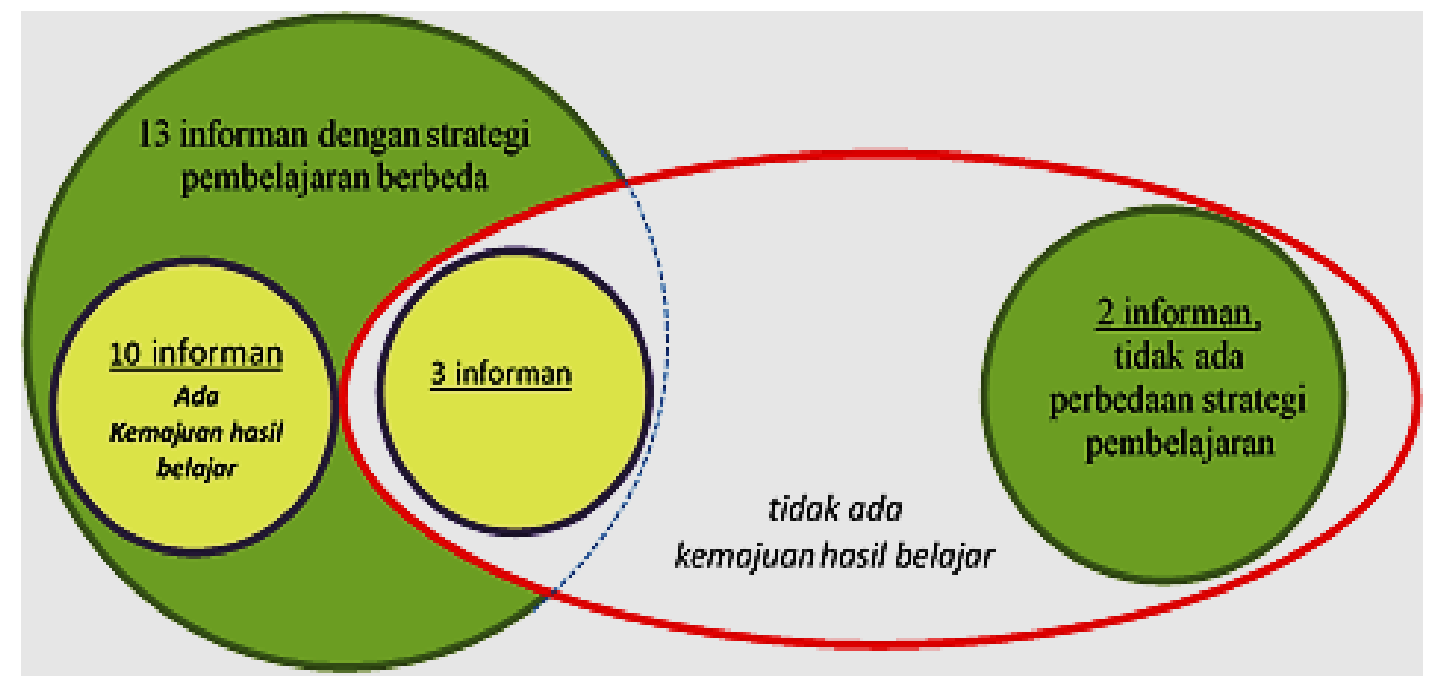

Diagram 2. The Difference in Learning Outcomes of Students with Special Needs Before and After the Application of Distance Learning

As illustrated in Diagram 2, it can be seen those 5 informants ( 2 informants who did not make changes to learning procedures and strategies and 3 informants out of 13 informants who have modified learning strategies) said that they did not progress to differences in Indonesian learning outcomes. Meanwhile, 10 informants from 13 informants who had modified learning procedures and strategies said that students with special needs had progressed as seen from the differences in Indonesian learning outcomes. The form of changes in student abilities in the form of progress in mastery of Indonesian language competencies can be seen in Table 2.

Table 2. Increasing Mastery of Indonesian Language Competencies

\begin{tabular}{|c|c|}
\hline $\begin{array}{c}\text { Indonesian } \\
\text { Language } \\
\text { Competence }\end{array}$ & Form of Increasing Indonesian Language Competency Mastery \\
\hline
\end{tabular}




\begin{tabular}{|c|l|}
\hline Reading & Reading ability improved significantly (more fluent in reading). \\
\hline Listening & $\begin{array}{l}\text { Increased ability to understanding the reading text/material } \\
\text { presented. }\end{array}$ \\
\hline \multirow{2}{*}{ Writing } & $\begin{array}{l}\text { Increases the vocabulary of objects in the environment and make } \\
\text { simple sentences from the vocabulary. }\end{array}$ \\
\cline { 2 - 2 } & Ability to write more neatly. \\
\cline { 2 - 3 } & The writing of letters is clearer and more emphatic. \\
\hline \multirow{2}{*}{ Speaking } & $\begin{array}{l}\text { Increased speaking skills in presenting work/assignments to be } \\
\text { smoother. }\end{array}$ \\
\cline { 2 - 2 } & $\begin{array}{l}\text { In students who experience speech delay, students show an } \\
\text { increase in pronouncing sentences correctly and intact. }\end{array}$ \\
\hline
\end{tabular}

Based on the data in Table 2, it can be seen that the four basic competencies in Indonesian, in general, have improved. These language competencies include the ability to read, listen, write, and speak. Reading ability is the most significant increase in incompetence from the data that has been collected. This is because, with distance learning, students are required to learn to read information or instructions conveyed by the teacher with the help of parents so that students become accustomed to reading activities. In listening ability, if students can understand the material conveyed by the teacher directly or through the help of parents, then the student can listen to the material they receive. Students' writing skills were also considered to be getting better and becoming tidier. This is because there are assignments that must be done by students by handwriting. This writing habit causes students' writing to become better and tidier. Likewise with the ability to speak. The activity of conveying or presenting the results of student work, makes students' speaking skills increase.

\section{Conclusion}

The findings from research on the implementation of Indonesian language learning in inclusive elementary schools in Yogyakarta show that the distance learning strategies for students with special needs during the pandemic have a significant effect. The strategy component that has the most influence is the selection of the learning media used. The more interactive the media used, the more effective the learning outcomes obtained by students. However, this also cannot be separated from the role of parents in assisting students during learning.

Based on the results of the discussion, teachers with the GPK collaboration also have plans for implementing learning strategies in the new normal, including by conducting home visits according to health protocols, holding face-to-face learning in turns with restrictions on the number of students, and being carried out interactively through concrete media, reducing the target/material by implementing collaborative learning, packaging learning media in the form of games, and using attractive teaching aids for all students (ABK and regular). The involvement of government, educators, 
parents, and society is very important in realizing inclusive education that is friendly to all. It can also develop an education system that can provide a way out for the education of children with special needs anywhere and in any situation.

\section{References}

Cahyadi, Ani. (2018). Pengembangan Media dan Sumber Belajar: Teori dan Prosedur. Serang: Penerbit Laksita Indonesia.

CNN Indnoensia. (2020). "Corona dan Dilema Guru Mengajar Siswa Berkebutuhan Khusus". Artikel Online. Diakses pada 30 Mei 2020 dari https://www.cnnindonesia.com/nasional/20200421163541-20-495770/coronadan-dilema-guru-mengajar-siswa-berkebutuhan-khusus.

Departemen Pendidikan Nasional. (2003). Undang-Undang Republik Indonesia Nomor 20 Tahun 2003 tentang Sistem Pendidikan Nasional. Jakarta: CV Mitra Karya.

Jamal, Samsul. (2020). “Analisis Kesiapan Pembelajaran E-Learning Saat Pandemi Covid19 di SMK Negeri 1 Tambelangan”. Jurnal Nalar Pendidikan. 8.1 (2020): 16-22.

Kementerian Pendidikan dan Kebudayaan. (2020). "Pandemi Juga Telah Menyadarkan Sejumlah Pihak Bahwa Pembelajaran Tidak Hanya Terbatas di Sekolah". Artikel Online. https://psma.kemdikbud.go.id/index/news detail.php?id=MTY1OA== diakses pada 1 November 2020 pukul 13.30 WIB.

Munir. (2009). Pembelajaran Jarak Jauh Berbasis Teknologi Informasi dan Komunikasi. Bandung: Alfabeta.

Nazir, Muhammad. (1998). Metode Penelitian. Jakarta: Galia Indonesia.

Winarsih, Sri, dkk. (2013). Panduan Penanganan Anak Berkebutuhan Khusus Bagi Pendamping (Orang Tua, Keluarga, dan Masyarakat). Jakarta: Kementrian Perlindungan Anak dan Perempuan.

Rustaman, N. (2001). Ilmu dan Aplikasi Pendidikan. Bandung: Inperial Bakti Utama.

Sugiyono. (2010). Metode Penelitian Pendidikan (Pendidikan Kuantitatif, Kualitatif, dan $R \& D$. Bandung: ALFABETA.

Surat Edaran Kemendikbud No. 4 Tahun 2020. "Pelaksanaan KebijakanPendidikan dalam Masa Darurat Penyebaran Corona Viru Disease Covid 19". Surat Edaran Online Resmi. Diakses pada 30 Mei 2020 dari https://pusdiklat.kemdikbud.go.id/suratedaran-mendikbud-no-4-tahun-2020-tentang-pelaksanaan-kebijakan-pendidikandalam-masa-darurat-penyebaran-corona-virus-disease-covid-1-9/

Zain, Aswan dan Syaiful Bahri Djamarah. (1997). Strategi Belajar Mengajar. Jakarta: Rinneka Cipta. 